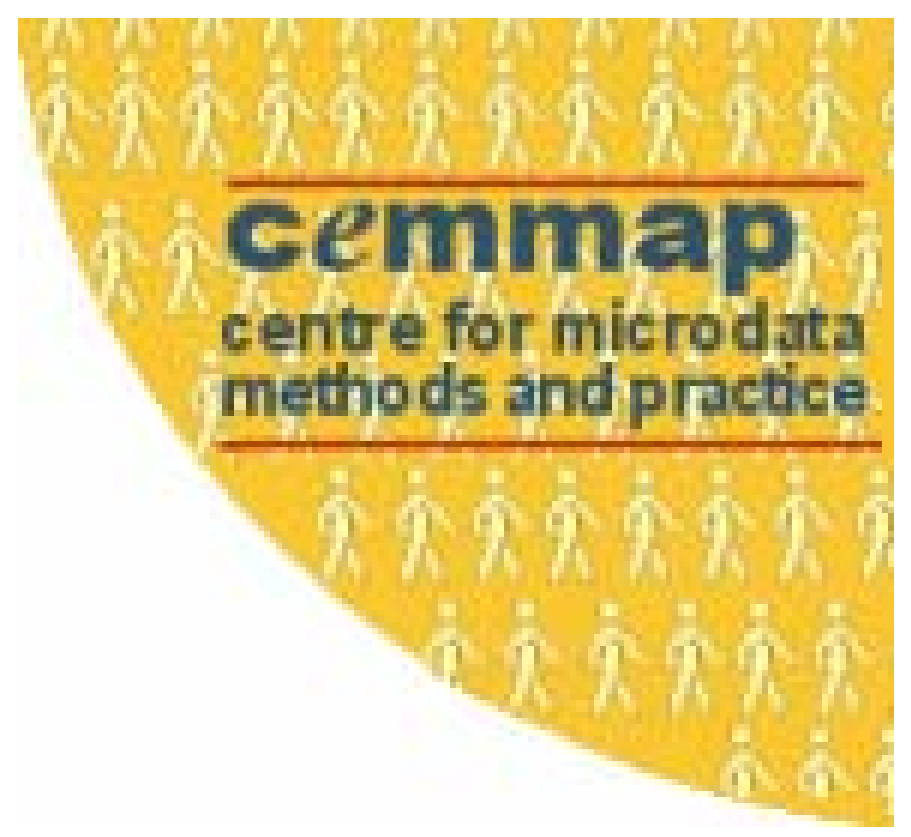

\title{
ENFORCEMENT OF REGULATION, INFORMAL LABOR AND FIRM PERFORMANCE
}

\author{
Rita Almeida \\ Pedro Carneiro
}

THE INSTITUTE FOR FISCAL STUDIES DEPARTMENT OF ECONOMICS, UCL cemmap working paper CWP02/06 


\title{
Enforcement of Regulation, Informal Labor and Firm Performance
}

\author{
Rita Almeida* \\ World Bank \\ Pedro Carneiro \\ University College London, Institute for Fiscal Studies \\ and Center for Microdata Methods and Practice \\ January 12, 2006
}

\begin{abstract}
This paper investigates how enforcement of labor regulation affects the firm's use of informal labor and firm performance. Using firm level data on informal employment and firm performance, and administrative data on enforcement of regulation at the city level, we show that in areas where law enforcement is stricter firms employ a smaller amount of informal employment. Furthermore, by reducing the firm's access to unregulated labor, stricter enforcement is also associated with lower labor productivity. We control for different regional and firm characteristics, and we instrument enforcement with a measure of the access of labor inspectors to firms. Taken together, our findings suggest that increased access to labor flexibility significantly improves firm performance.
\end{abstract}

Keywords: Informal Sector, Labor Markets, Regulation, Productivity.

JEL Classification codes: J3, J6, O17.

*Corresponding author: Rita Almeida (ralmeida@worldbank.org). We thank the Brazilian Ministry of Labor for providing us the data on enforcement of labor regulation that we use in our paper and important information about the process of enforcement, especially Edgar Brandao, Sandra Brandao and Marcelo Campos. We thank Loren Brandt, Robin Burgess, George Clarke, Flavio Cunha, Saul Estrin, Ana Fernandes, Mary Hallward-Driemeier, John Haltiwanger, Jennifer Hunt, Adriana Kugler, Sara Lemos, Norman Loyaza, David McKenzie, Stefano Scarpetta, Luis Serven, Rodrigo Soares, Eric Verhoogen and participants in SOLE/EALE 2005 meetings, IZA conference on Transition Economies (Bologna) Microeconomics Development Network Meeting (Beijing) and WB research seminar for valuable suggestions. Carneiro thanks the hospitality of the Poverty Unit of the World Bank Research Group. 


\section{Introduction}

In most developing countries, strict labor market regulations imply high costs of employing formal workers and low labor flexibility. These regulations also create a strong incentive for firms to overcome regulation and hire informally. Because law enforcement is imperfect and monitoring is costly, several firms in developing countries evade labor regulation, and use informal rather than formal workers. The additional flexibility given by informal workers, coupled with possibly lower labor costs, is likely to translate into better firm performance for firms that evade the law (provided that the costs of evading the law are not too large). Quantifying this effect is important to understand the efficiency costs of strict labor market regulations. ${ }^{1}$ In developing countries, the size of the informal labor market suggests that there is a large difference between the de jure and the de facto labor regulation. Thus, when evaluating the effects of regulation on performance we can explore variation in the enforcement of labor regulation since it is conceptually closer to changes in the de facto regulation faced by firms.

Our paper quantifies the effects of labor regulation on the employment of informal labor and on different measures of firm performance exploring the fact that labor regulation is not enforced uniformly within a country. In particular, we will examine two issues on which our current empirical knowledge is quite limited. First, we study how changes in enforcement affect the firm's demand for informal labor. Second we analyze how it affects firm performance, possibly through changes in the firm's access to informal labor. Nevertheless, not all the variation in our measure of enforcement across regions can be considered exogenous. Some regions could have higher enforcement simply because they have a higher level of informality (reverse causality); or because they are more developed, and (due to a better institutional environment) development could be positively correlated with enforcement and negatively correlated with informality (omitted variables). Moreover, the probability of get-

\footnotetext{
${ }^{1}$ Most papers quantify the efficiency costs of strict regulation for labor outcomes like employment, unemployment and wages (Freeman, 1988, Blanchard and Wolfers, 2000, Nickell, 1997, Nickell and Layard, 2000). Although less studied labor regulations will also affect the firm's demand for labor as well as the firm's investment strategies and productivity (Holmes, 1998, Besley and Burgess, 2004).
} 
ting a fine can be a function of firm characteristics and of its efforts to avoid regulation (for example, large and publicly owned firms are more visible to labor authorities, see Loayza, 1996). To minimize these problems, in our empirical work we control for an extensive set of firm and regional variables which are likely to be important determinants of informal behavior, firm performance and enforcement. In addition, we instrument enforcement with a measure of accessibility of labor inspectors to firms (and control for differences in the general law enforcement across regions).

We use data for Brazil, a country with one of the most regulated labor markets in the world. Furthermore, enforcement of the law is apparently weak since more than $40 \%$ of total employment is in the informal sector. Even though labor regulation is the same in all Brazilian states, its enforcement is highly decentralized. This generates considerable variation in the degree of government monitoring faced by firms in different areas. For Brazil there are three good sources of data which we combine in our study. First, we use a firm level dataset collected by the World Bank with standard information on investment, employment, sales and value added, and with unique information on the employment of informal workers (and other types of illegal behavior of firms). Second, using administrative data from the Ministry of Labor we construct measures of the enforcement of labor regulation at the city level. Third, we use information collected by two Brazilian statistical and research institutes on the economic and demographic characteristics of all the cities where the firms in our sample are located.

Our findings show that increased enforcement of labor registration in the area where firms are located leads to a substantial reduction in the evasion of regulation since the number of informal workers they employ is reduced. Furthermore (by reducing the firm's access to unregulated labor) stricter enforcement also leads to large decreases in value added and profits per worker, and to reduced employment in the firm. The elasticities of informal employment and labor productivity with respect to enforcement are approximately -0.14 and -0.1 (respectively). The elasticity of labor productivity with respect to informal employment is 0.73 .

Our paper contributes to and integrates insights from the literature on regulation, infor- 
mality, crime and labor demand. First, we relate to the literature that analyses the effects of labor market regulation on economic efficiency. Part of this literature explores cross country variation in the labor regulation to identify the effects of more restrictive labor regulation on aggregate outcomes (e.g., Botero, Djankov, La Porta, Lopez-de-Silanes and Shleifer, 2004, Nickell and Layard, 2000 and Heckman and Pages, 2003, Lazear, 1990, Blanchard and Wolfers, 2000). These cross country studies suggest that stringent labor marker regulation hampers economic efficiency. However, the identification and measurement problems of this literature coupled with the increasing availability of large micro data sets have motivated new analysis exploring within country variation in regulation. Recently, several papers focus on specific changes in labor regulations (e.g., Barros and Corseuil, 2001) or social security payments (e.g. Gruber, 1997, Kugler and Kugler, 2003). More closely related to our analysis is Holmes (1998) and Besley and Burgess (2004). Holmes (1998) explores variation across US states and shows that those that enacted pro-business right-to-work laws had increases in manufacturing activity. Besley and Burgess (2004) also find important effects of labor regulation on output, employment, investment and productivity in Indian manufacturing. The main differences relatively to our paper are that we are exploring variation in the enforcement of labor regulation (as opposed to variation in regulation itself) and we are using firm level data (instead of aggregate regional data; see also Boeri and Jimeno, 2005). This allows us to study both the relationship between regulation and firm performance, and the relationship between enforcement and illegal behavior.

Second, our work also relates to the literature on informality. Direct and indirect tax rates as well as stringent labor regulations are usually found to be strong determinants of the size of the informal sector across countries (e.g., De Soto, 1989, Loayza, 1996, Schneider and Enste, 2000). However, enforcement of regulation and the quality of institutions are also important determinants of the way regulation affects informality (e.g., Johnson, Kaufmann and Zoido-Lobaton, 1998, Loayza, Oviedo and Serven, 2005). The modern micro literature on informal labor markets (e.g., Maloney, 2004) suggests that we should look at the formal and informal sectors in an integrated way (as opposed to a segmented view of the labor market) and emphasizes the role of the informal sector as a source of unregulated labor to 
firms. This is the basis of the economic reasoning underlying our work.

Finally, we relate to the literature on the economics of crime. Even though the incentives of criminals and the determinants of law enforcement have been studied extensively (e.g., Becker, 1962, Levitt, 1997, 1998 and 2004, Polinsky and Shavell, 2000) very little is known empirically about the firm's incentives to overcome regulation and how enforcement of labor regulation can reduce informal firm behavior. Our estimates of the elasticity of use of informal workers with respect to enforcement are similar in magnitude to those found in other contexts by Levitt (1998) and Bar-Ilan and Sacerdote (2004). ${ }^{2}$ These two papers find that the elasticity of crime with respect to enforcement is about 0.2 .

Our paper is organized as follows. In section 2 we describe the Brazilian labor market, the enforcement of regulation in Brazil, and the main data sets that we use. Section 3 briefly lays out a simple theory underlying our empirical work. In Section 4 we analyze the relationship between enforcement and informal employment. In section 5 we present estimates of the importance of labor flexibility for firm labor productivity and other performance indicators. Section 6 concludes.

\section{Data}

\subsection{Measuring Labor Informality}

We use firm level data from the Brazilian Investment Climate survey collected by the World Bank in 2003. The survey is representative of a set of manufacturing sectors (details of the survey are given in the data appendix and descriptive statistics of the main variables are reported in table A1 in the appendix). Of particular interest to us is available (and highly unusual) information about the degree of labor informality in the firm. The question on informal employment is phrased indirectly to avoid implicating the respondent in wrongdoing: "Given the constraints to hire workers and the additional costs that it entails, in your

\footnotetext{
${ }^{2}$ We do not explicitly examine the damage illegal behavior inflicts on institutions and social protection. However, on the latter point the available evidence is not clear. Even though labor market institutions are usually used to explain differences in inequality across developed countries (e.g., Blau and Khan, 1996), it has been repeatedly shown that regulation can actually be detrimental to poverty and inequality in developing countries (e.g., Besley and Burgess, 2004, and the essays in Heckman and Pages, 2003).
} 
opinion, what is the percentage of the permanent employment that is informal/unregistered in a typical firm of this size and in this industry?". 3

We will assume the answer to this question to be a good indicator of the firm's own degree of labor informality. Even though very similar questions have been used successfully in the study of corruption (Svensson, 2003), there can be doubts about the extent to which the answer to this question measures the degree of informality of the respondent firm. Several arguments support our use of this variable. Although none of them is definitive, taken together they suggest our use of this variable is valid. First, firms are asked to judge to what degree similar firms generally comply with labor law. We find that $41 \%$ of the firms in the sample simultaneously claim that their competitors comply perfectly with labor law and (answering the informality question which we use here) state that similar firms hire a positive percentage of informal workers. Such responses would be inconsistent unless firms that were similar to the respondent firm were not its major competitors (which is unlikely), or if the answer to the question on informal employment really corresponded to the degree of informality of the respondent and not of a group of similar firms. Second, firms also report their labor costs, inclusive of a variety of taxes and social security payments. We observe that firms employing informal workers (according to our definition) pay on average $61 \%$ lower taxes and social security payments per employee than those only hiring legal workers (according to our definition). Even after controlling for industry, location and the average net wage in the firm, firms employing informal workers pay on average $16 \%$ lower taxes and social security payments per employee, suggesting that these firms are able to evade social security payments. If the answer to the question above were not related to the percentage of informal workers employed by the respondent firm this relationship would probably not

\footnotetext{
${ }^{3}$ Approximately $65 \%$ of the firms report a positive number of informal workers and, on average, these represent approximately $36 \%$ of the permanent workforce. $10 \%$ of the firms have missing information in the informality question, but do report data for sales, capital and other inputs. The missing data raises questions relative to possible sample selection. We check whether firms with missing information also decline answering other questions that also would implicate them in wrongdoing. We find no evidence that firms avoid all wrongdoing questions (e.g., indirect evidence on the sales reported for tax purposes). About $70 \%$ of the firms that do not answer the question on labor informality, do answer the question on (indirect) tax evasion. Furthermore, firms that do not report data on informal workers are not statistically different from firms that report this information on a variety of dimensions (results available upon request).
} 
take this form so clearly. Third, firms are asked whether they would like to change their workforce if they had no hiring or firing costs. We find that those firms reporting that they would like to change their workforce are 20 percentage points more likely to report using informal labor. Fourth, we find that managers who report that labor regulations are a severe obstacle to their business are more likely to report employment of informal workers.

Table 1 presents differences across different variables between firms reporting a positive number of informal workers and firms reporting no use of such workers in our sample. ${ }^{4}$ These firms are on average younger and smaller (in total employment, physical capital, value added, sales and profits) than those reporting no informal employment. They have a less educated workforce and are less likely to be foreign or state owned than fully legal firms. They are concentrated in low skilled/labor intensive sectors (like clothing, shoes and wood products) and are less likely to manufacture chemicals, machinery and electronic products. ${ }^{5}$ Finally, they are more likely to pay bribes to government officials (conditional on doing business with the government) and are also more likely to underreport their sales for tax purposes than firms only hiring formal workers. ${ }^{6}$

\subsection{Enforcement of Labor Regulation}

All employees in Brazil must have a work permit on which the employment history of the worker is registered (carteira de trabalho). This permit officially entitles the worker to several wage and non-wage benefits paid for by the employer, such as retirement benefits, unemployment insurance, and severance payments. These benefits increase the employer's costs

\footnotetext{
${ }^{4}$ We estimate an equation of the following form: $y_{j}=\beta D I_{j}+\gamma_{s} D_{s}+\delta Z_{r}+\epsilon_{j}$, where $y_{j}$ is the outcome of interest, $D I_{j}$ is a dummy variable that equals one if the firm reports using informal workers, $D_{s}$ are sector dummies and $Z_{r}$ are regional characteristics at the subregional level (log total number of plants in the subregion, $\log$ of population in the subregion in 2000 and the log of GDP per capita in 2000). Column (1) reports the least squares estimates of $\beta$ not including $D_{s}$ and $Z_{r}$ and column (2) reports the estimates controlling for $D_{s}$ and $Z_{r}$.

${ }^{5}$ These sectors are more likely to have a certificate of quality and to develop internally and/or jointly with costumers or suppliers new technology. They also have more educated workers and pay higher wages.

${ }^{6}$ The data set we use only includes registered firms. If we assume that unregistered firms only includes informal workers, our data is truncated (it only includes firms for which informal employment is below 100\%). In the empirical section, we will briefly describe how we address this problem and we suggest that it is not an important concern for our results.
} 
of hiring formal workers because of taxes and other mandatory worker benefits (FGTS ${ }^{7}$, thirty days of paid leave, dismissal notification period and maternity/paternity paid leave). In the case of informal hires most of these benefits are negotiated on a case-by-case basis between the employer and the employee. A major incentive for firms to hire informally is to avoid mandatory payments to the government (e.g., social security payments) which in Brazil can amount to $100 \%$ of the net wage paid to the worker. For a general description of the Brazilian labor regulation and its recent changes see Barros and Corseuil (2001).

Compliance with labor regulation in Brazil is enforced by the Ministry of Labor. Given the size of the country, enforcement is first decentralized at the state level ( the state level labor office is called delegacia) and then at a more local level, the subregion, which includes several cities (the local labor office is called subdelegacia). This is the relevant level of variation for the enforcement data because labor inspectors are affiliated with a particular subdelegacia and report to the head of the subdelegacia (subdelegado). Labor inspectors visit firms within the corresponding subregion, assessing their compliance with several dimensions of labor law (e.g., worker's formal registration, compliance with minimum wages). All labor violations are punishable with fines (in the appendix we provide more detail on the enforcement structure). Since we study the determinants of the use of informal labor and the effects it has on firm performance, the enforcement measure that we use is the number of fines in the subregion related specifically to irregularities that concern worker registration, or registration fines. ${ }^{8}$ This is ultimately the relevant fine for firms deciding whether or not to evade the law and hire informally. Because some subregions are larger and have more firms than others, we normalize number of fines by 1000 firms in the subregion. Unfortunately,

\footnotetext{
${ }^{7}$ The Fundo de Garantia por Tempo de Servico (FGTS) is a government administered fund paid by the employers that is accumulated while the worker is employed. Unfairly dismissed workers have access to their fund.

${ }^{8}$ When a worker is found unregistered the inspector notifies the firm of its violation. After receiving a notification, the firm has 10 days to present evidence in its defense. Because it is the firm's responsibility to register the worker's contract, once notified it is very difficult to prove its innocence. Exceptions include the cases where a third party is responsible for the registration (e.g. union). Therefore, even though a notification does not imply a fine, in the particular case of the registration of workers, it almost always does. A firm is fined 300 Reais (USD \$130) for each worker that is found unregistered during an inspection (which can occur more than once a year). The fine is reduced by $50 \%$ if the firm pays within 10 days of the date of notification.
} 
fines are not a clean measure of enforcement (which is unobserved in our data set), but result from the interaction between crime and enforcement. In the next section, we describe the potential problems that can arise from measuring enforcement in this particular way.

There is an effort to apply an homogeneous criteria in the enforcement of labor regulation throughout the country, but in practice this is very difficult to achieve. Enforcement is not likely to be uniform across subregions because Brazil covers a very large and diverse geographical area, the number of inspectors involved is also large, and they are probably very heterogeneous in their ability and honesty (which is important in the case inspectors are offered bribes). This gives rise to substantial regional variation in enforcement.

\section{Theory}

We consider a firm choosing simultaneously two types of labor (formal and informal), capital and the technology of production. Technology, capital and formal labor are quasi fixed inputs, while informal labor can be flexibly adjusted every period. We think about informal workers as being less costly and more flexible than formal sector workers. The additional flexibility of informal labor is due, for example, to lower hiring and firing costs (Oi, 1962), or to the lack of regulation in working hours. Informal workers do not receive other mandatory benefits (e.g., social security contributions) and their employers do not have to comply with job protection regulations (e.g., dismissal costs). Suppose, for now, that there are no other differences between these two types of workers (e.g., differences in skills). ${ }^{9}$ Then informal workers are unregulated workers who coexist with formal workers in a single labor market, as opposed to having segmented labor markets (e.g., Maloney, 2004).

With strict labor regulation and imperfect monitoring, firms can either choose to comply with regulation, or they can ignore the law and use informal workers. Those firms who evade the law face the cost of being caught in labor inspections and being forced to pay a fine for employing informal workers. As enforcement becomes stricter, the cost of evading labor

\footnotetext{
${ }^{9}$ We only consider differences between formal and informal workers not between formal and informal firms (our assumption is that all firms are fully registered, although part or all of their workers may not be legally registered).
} 
regulation increases and, all else constant, there should be a reduction in the use of informal labor. Our conjecture is that reduced access to cheaper and more flexible labor will translate into better firm performance.

In particular, we predict that a reduction in the cost of flexible labor translates into a lower cost of production, and therefore, into an increase in output. Similarly, because labor is cheaper, we also predict an increase in employment. As for the effect on capital, it depends on its complementarity with labor and on potential hold-up problems (e.g., Besley and Burgess, 2003).

One practical difficulty that we face in our empirical work is that we do not directly observe enforcement, since we only observe fines. Let $F$ be fines, $C$ be the amount of crimes committed and $E$ be the level of enforcement. Then, $F=f(C, E), \frac{\partial f}{\partial C} \geq 0$ and $\frac{\partial f}{\partial E} \geq 0$. Furthermore, crime is a function of enforcement: $C=g(E)$, where $\frac{\partial g}{\partial E} \leq 0$. Given that we observe $C$ in our data, if we also observed $E$ then we could be able to estimate $g(E)$, one of the goals of our paper. However, we do not observe $E$, but only observe $F$. In section 4, we regress $C$ on $F$ and, just in an accounting sense, the relationship should be positive since, for fixed enforcement, more crime generates more fines. If most of the variation in $F$ is due to variation in $E$ then we may observe a negative relationship between $C$ and $F .{ }^{10}$ In the empirical section, we will show that this is indeed the case. Therefore, since $\frac{\partial C}{\partial F}<0$ in our data we will argue that most of the variation in $F$ is being driven by variation in $E$. If anything, variation in $F$ understates variation in $E$. Furthermore, ultimately we use an instrumental variable approach where the variation in fines which we explore is driven by variation in the access of labor inspectors to firms. In other words, the variation in fines is driven by exogenous variation in enforcement capacity, which is the relevant variation we want to use in this study.

\footnotetext{
${ }^{10}$ Let $d F=\frac{\partial f}{\partial C} d C+\frac{\partial f}{\partial E} d E$ and $d C=\frac{\partial g}{\partial E} d E$. Substituting $d E$ into the first expression: $d F=$ $\left[\frac{\partial f}{\partial C}+\frac{\partial f}{\partial E}\left(\frac{\partial g}{\partial E}\right)^{-1}\right] d C$. Then, $\frac{\partial C}{\partial F}$ will be $\leq 0$ if $\frac{\partial f}{\partial C}$ is small relative to $\frac{\partial f}{\partial E}\left(\frac{\partial g}{\partial E}\right)^{-1}$, i.e., if most of the variation in $F$ is due to variation in $E$.
} 


\section{Enforcement of Labor Regulation and Informal Labor}

We start by analyzing the main determinants of labor regulation. Table 2 reports the results of regressing registration fines per firm in the subregion on different demographic, institutional and economic variables (as opposed to weighting by the number of firms in the subregion, this regression includes only one observation per subregion, a there is a total of 77 subregions in our sample). We present four basic specifications. Column (1) is our basic specification. In column (2) we add the number of train stations in the subregions, a measure of access of labor inspections to firms in the area. In column (3) we add total labor fines, a measure of potential illegal behavior and of general law enforcement in the area and in column (4) we include all variables. We believe that total labor fines can be a measure of potential illegal behavior in the area if more crime leads to more fines. Total labor fines could also be a proxy for the overall strictness of law enforcement in the area (we expect to have stricter enforcement of the registration of workers in places where we also observe stricter enforcement of other types of labor regulation).

We find that very few variables are systematically and strongly related with registration fines across subregions, suggesting that the variation in enforcement that we are using is close to random (and hopefully exogenous). In the first two columns, the total number of plants seems to matter, but this may just be due to measurement error since this is the denominator of our left hand side variable (recall that we normalized enforcement by the number of plants in the region). Past GDP in the region also seems to play some role in the determination of fines, suggesting that regions with better past performance develop better institutions and therefore are able to enforce the law more strictly. Finally, total fines in the subregion (which include fines for violation of all types of labor regulation, not only informality fines) are strongly correlated with registration fines, and the same is true for the number of train stations in the subregion. The greater the accessibility of inspectors to the cities in their subregion - proxied by the number of train stations- the larger is the number of worker registration fines. The findings are supportive of the idea that costly access to cities decreases the amount of inspections and fines faced by firms. Below we elaborate on 
using this variable as an instrument for registration fines in the area. ${ }^{11}$

To examine the effect of enforcement of labor regulation on informal employment hired by the firm, we estimate the following equation:

$$
{\frac{\operatorname{Inf}}{E m p_{j}}}_{j}=\beta E_{r}+X_{j} \gamma+Z_{r} \delta+\varepsilon_{j}
$$

where $\frac{I n f}{E m p}$ is the proportion of informal workers in the total employment of firm $j, E_{r}$ is enforcement of worker's registration in subregion $r$ where firm $j$ is located, $X_{j}$ is a vector of firm characteristics and $Z_{r}$ are demographic, institutional and economic controls. We assume $\varepsilon_{j}$ is an i.i.d. error term and cluster the standard errors at the subregion level. ${ }^{12}$ We expect that $\hat{\beta}<0$ since increasing the enforcement of worker's registration, increases the cost of using informal labor. Table 3 reports the least squares estimates of equation (4.1) for different specifications.

In column (1) the estimated effect of enforcement on informal employment is strongly negative. However, the variation in registration fines in this column is likely to be correlated with error term. We enumerate three possible reasons. First, some regions have higher enforcement of worker registration simply because they have more informality. The positive correlation between informality and enforcement is similar to the argument that "more crime leads to more police" (e.g., Levitt, 1997, 2004). This "reverse causality" bias is likely to cause $\hat{\beta}$ to be upward biased. Another possibility is that firms with a lower proportion of informal employment prefer to locate in more developed regions where institutions are better and inspections are more rigorous for some other reason (e.g., better infrastructures). This bias generates a negative correlation between enforcement and informal behavior, leading to a downward bias in $\hat{\beta}$. Similarly, if firms wishing to hire informal workers sort into areas where enforcement is less strict, $\hat{\beta}$ is downward biased.

\footnotetext{
${ }^{11}$ Ours might not be a good measure of access since trains in Brazil are only used for transporting goods, not people. However, if trains and bus connections are correlated we can use the former to proxy for the latter. We assume that this is the case throughout the paper. Furthermore, as an empirical fact, in our data train stations are strongly correlated with enforcement.

${ }^{12}$ Equation (4.1) is not an explicit labor demand equation but can be related to it in a partial equilibrium framework, where the prices of different inputs are kept fixed when enforcement varies across firms. However, a labor demand equation would have the number of informal workers employed by the firm on the left hand side instead of the proportion of informal workers in total employment.
} 
In order to isolate the exogenous variation in enforcement from variation in enforcement due to differences in potential informality across regions (informality that would exist across regions if there were no enforcement), endogenous sorting of firms, or third factors correlated with both enforcement and informality, we start by controlling for different firm and regional characteristics. In column (2) we control for variables that are likely to be good indicators of the degree of potential informality in the firm and that are also likely to be fairly exogenous $\left(X_{j}\right)$ : age of the firm, share of public ownership in the firm, and industry dummies. We also control for regional variables $\left(Z_{r}\right)$ like the log of the current and past level of GDP per capita in the subregion, log of current and past level of population in the subregion, log of total number of plants in the subregion, the share of females in the city and in the subregion and the log of average city area in the subregion. These variables could be determinants of the degree of potential informality in the region or factors that simultaneously explain informality and enforcement. The point estimate for $\hat{\beta}$ after controlling for these variables becomes smaller (more negative) suggesting that reverse causality bias may be important.

To account for the possibility that enforcement of worker's registration could be higher in regions where enforcement of the law in general (not only labor law) is stricter, column (3) controls the average number of homicides per 100 thousand inhabitants in the cities of the subregion. This variable is meant to capture the severity of police enforcement in the area. A priori, there is no reason for the homicide rate to be correlated with informal behavior of the firm except through third factors that are correlated with general enforcement of the law in the subregion and may also affect the enforcement of this specific labor law. Because general law enforcement tends to be positively correlated with the enforcement of the worker's registration, the estimate for $\hat{\beta}$ increases slightly relatively to column (2). Across columns, the effect of enforcement on informality is strong and negative. Therefore, our conclusion is that enforcement is a tool that can potentially be used by governments to effectively fight noncompliance with the law.

Due to the unusual nature of our dependent variable and to the way the question is asked in the survey we may be concerned with measurement error. Measurement error in the dependent variable is not usually a problem, unless it is correlated with the independent 
variable of interest. In particular, firms may underreport informal behavior when they are faced with strict enforcement. In this case $\beta$ captures the effect of enforcement on both informal behavior and on missreporting, and therefore is an overestimate of the true deterrent effect of enforcement. Even though we cannot address this concern, as a robustness check we have replicated our results using a transformation of our dependent variable: a dummy which takes the value 0 if the firm reports no illegal employment and the value 1 if the firm reports any informal employment. Our results are essentially the same: all the effects negative and strongly significant (results available on request). However, there is no way to say whether this transformation exarcebates or dampens the potential measurement error problem. Another potentially serious problem is that the dependent variable is censored at zero. When we estimate a tobit model instead of a least squares regression our estimates become slightly more negative. Finally, because we only observe registered firms our sample is truncated since we never observe firms where the proportion of informal workers is $100 \%$ (informal firms). Running a truncated regression instead of a least squares regression leads essentially to similar results (all these robustness checks are available on request). ${ }^{13}$

There could be some concern that the control variables included in table 3 are not enough to drive the correlation between enforcement and the error term of equation (4.1) to zero. Table 4 reports the our estimates when we instrument worker's registration fines with a measure of the inspector's accessibility to the cities within the subregions: total number of train stations in the cities of the subregion. We conjecture that conditional on firm and regional characteristics the number of train stations is uncorrelated with the firm's decision to hire informal workers except through the accessibility of the inspectors to the cities, i.e., through the extent of enforcement in the subregion. The better the access of inspectors to the cities, the lower will be the costs of enforcing the regulation. Our instrument is likely to be related to regional economic development, industrial composition, or population density

\footnotetext{
${ }^{13}$ Since the enforcement of different types of labor regulation is very strongly correlated, it is possible that the results in table 3 are capturing the effect of the enforcement of an alternative type of labor regulation, or the effect of stricter labor enforcement in general. Table A2 (in the appendix) reports the results of reestimating the reduced form equation replacing our measure of enforcement with fines related with other labor violations. The results suggest that the strongest and clearest effect on the use of informal labor comes through the fines on worker's registration, and not through the other fines reported here.
} 
the region, all of which may be correlated with the informal behavior of firms. However, since in the regressions we control for several firm and regional characteristics, we only use the variation in the instrument that is orthogonal to all these variables.

Columns (1) to (5) differ in the controls included in the regression. Column (1) includes the same firm and regional controls as in column (3) of table 3. Our estimate of the effect of enforcement on illegal employment remains negative and statistically significant. In fact, it is smaller than the OLS estimates of table 3 suggesting that reverse causality is biasing those estimates upward. As a robustness check, column (2) adds total transportation cost (monetary) to the nearest capital city, which is meant to capture the accessibility to markets and the effect it could have on the use of informal labor. ${ }^{14}$ Column (3) includes an alternative measure of general law enforcement as a further robustness check: total labor fines per firm in the subregion. In this case we are measuring the effect of the enforcement of legal registration of workers relative to other types of labor enforcement. In both columns (2) and (3) the coefficient of interest remaing negative and strong. Another possible concern is that our measure of informality is simply capturing the propensity of the firm to engage in some form of informal behavior. To account for this, in column (4) we include the share of sales in the firm that is not reported for tax purposes as a control. Finally, in column (5) we want to control for the fact the some regions could have higher informality and lower enforcement simply because firms are more likely to bribe government officials when they are involved in government contracts. Controlling for these two variables leads to smaller point estimates for $\beta$ although in the last two columns the number of observations is dramatically reduced. ${ }^{15}$

\footnotetext{
${ }^{14}$ Train stations may be correlated with the performance of the firm if it measures access to markets. The index of the transportation cost to the nearest state capital - which can either be within the state or in a neighboring state- is meant to capture proximity to markets. This is a relevant variable for measuring access to markets but not for measuring access from labor inspectors, who operate only within state at the level of the subregion. Transportation costs is probably a more relevant control variable when we examine the effect of fines on firm performance, as in the next section. However, both the number of train stations and transportation costs measure access. We choose to use the former as an instrument and the latter as control because the latter measures distance to a major city, which basically measures access to markets, while the former is meant to represent a more local measure of distance, related to mobility costs that labor inspections face within their inspection area.

${ }^{15}$ In columns (4) and (5), both tax reporting and bribes are endogeneous variables. We do not wish to interpret their coefficients, but only to examine the sensitivity of our main results to their inclusion in the model. The number of observations is smaller because the question in bribes is asked only when the firm does business with the government, and because some firms choose not to answer the tax reporting question.
} 
We estimate that, on average, when the number of fines per 1000 firms in the subregion increases by 1 , the share of informal workers falls by 4.06 percentage points. In our sample, the average number of fines per 1000 firms in the subregion is 0.77 and the average proportion of informal workers in a firm is 0.23 . Based on these numbers we compute that an elasticity of illegal employment with respect to enforcement of -0.14 . This number is comparable to those obtained in the crime deterrence literature using US data: for example, Levitt (1998) finds that the elasticity of crime with respect to the arrest rate is about -0.2 , and Bar-Ilan and Sacerdote (2004) find that the elasticity of driving violations with respect to fines is also about -0.2 . In our sample, average enforcement of labor regulation is low and the average amount of violations is relatively high, so that an elasticity of -0.14 corresponds to a large absolute effect of fines on illegal behavior.

Finally, we check whether our results are driven by the general propensity of the firm to engage in informal behavior. Since different types of informal behavior tend to be correlated at the firm level, our estimates could be simply reflecting their negative correlation with degree of enforcement of regulation. To investigate this possibility, table 5 presents the results of least squares and IV regressions of the share of sales not reported for tax purposes on the same enforcement and control variables as in column (3) of table $3 .{ }^{16}$ We do not find any evidence supporting this concern. An increase in the enforcement of labor regulation leads to lower employment of informal labor but not to a lower level of tax evasion. This check also increases our confidence in the validity of our instrument. One would think that if number of train stations were correlated with informality except through its effect on enforcement (making it an invalid instrument) then it should also be correlated with things such as tax evasion (and other type of illegal behavior).

There is one source of bias that is difficult to address empirically: the endogenous sorting of firms with high propensity for illegal behavior into areas where law enforcement is less

\footnotetext{
${ }^{16}$ Again, the amount of tax evasion is self reported by the firm and therefore is also subject to measurement error. However, in results available on request, we show that firms reporting a smaller fraction of sales for tax purposes also employ more informal workers, are smaller and less productive than firms who report a large fraction of sales to tax authorities. This indicates that this variable has relevant information for our problem.
} 
strict. The reason is that it is almost impossible to find an instrumental variable that affects enforcement without also affecting the sorting behavior (since the latter is a reaction to the former). An alternative idea is to split the sample between groups of firms that are more mobile and less mobile. Provided that variation in enforcement across regions has an important time component (something we cannot assess with a single cross section), less mobile firms will be less able to change their location in response to changes in local enforcement. Therefore, if we restrict our sample to those firms our estimates may be less susceptible to this sorting bias. We cannot observe directly firm mobility, but we can observe other variables that should be good proxies for mobility, such as age, size and foreign ownership. Table A3 in the appendix reports the results of estimating equation (4.1) for groups of firms that are arguably less mobile (smaller, older and domestic owned firms whose location is typically determined by the residence of the owner). For these firms, there is still a robust negative correlation between enforcement of regulation and the use of informal workers.

\section{Enforcement of Labor Regulation and Firm Performance}

As argued above, we think about informal workers as being less costly and more flexible than formal sector workers. In the previous section we show that as enforcement becomes stricter the cost of evading labor regulation increases and, all else constant, the use of informal labor is reduced. Our conjecture is that such a reduction in the firm's access to cheaper and more flexible labor will translate into worse firm performance. Firms may respond to increased enforcement in several ways. For example, they may choose capital intensive technologies when enforcement is strict (avoiding large labor costs) and labor intensive technologies when enforcement is loose (Loayza, 1996). Alternatively, whenever enforcement is loose, firms can choose technologies that are more productive when labor is flexible, and these can be either labor intensive or capital intensive. Besley and Burgess (2004) find that pro-worker labor regulation in India (which makes labor more expensive) leads to lower investment, employment and labor productivity in the formal sector. Scarpetta and Tressel (2004) present 
evidence suggestive that the negative effect of labor regulation on productivity works through a reduction in the incentives for innovation and technology adoption. In this section we contribute to the study of the effect of labor regulation on economic performance by analyzing the relationship between enforcement of labor regulation and alternative indicators of firm performance in Brazil.

Table 6 reports the results of estimating a specification identical to equation (4.1) but where the dependent variable is the log of value added per employee. ${ }^{17}$ Again the OLS estimates in column (1) can suffer from different types of biases. Assume that subregions differ in characteristics that determine potential informality, i.e. the degree of informality that would exist if there were no enforcement. $\beta$ could be downward biased if firms located in areas with more potential informality are less productive because they are smaller, or they belong to a low productivity industry. Alternatively, more productive firms with smaller amounts of informal workers could locate in large cities where institutions are better and inspections are more rigorous. This will induce an upward bias in $\beta$. Finally, firms wishing to hire informal workers may sort into areas where enforcement is less strict, again biasing the estimate of $\beta$.

The least squares estimates in column (2) show that stronger enforcement of labor regulation seems to be associated with weaker firm productivity even after controlling for several firm and regional variables. In columns (3) and (4) the instrumental variable estimates tend to be slightly more negative than the least squares estimates. This suggests that enforcement is stricter in regions with better performance and that this was not being accounted for by the least squares estimates. As in the previous section, in column (4) we control for an index of transportation cost to the nearest state capital - which can either be within the state or in a neighboring state- because train stations could measure access to markets. ${ }^{18}$ Finally,

\footnotetext{
${ }^{17}$ Although we do not estimate an explicit production function, the (reduced form) relationship we estimate between value added and enforcement can be derived from a standard profit maximization problem with multiple types of labor which have different flexibility and different costs. It is also similar to the specification of Besley and Burgess (2004) and of other papers in the literature on labor regulation and economic performance.

${ }^{18}$ We assume that conditional on the firm and regional controls (GDP per capita, population, number firms, homicide rate, average city area and transportation costs), the number of train stations is uncorrelated with firm performance except through worker's registration fines. Assuming that the instrument and firm
} 
in column (5) we add a measure of total labor law enforcement. In both these columns the effect of enforcement on productivity remains negative and statistically strong. The point estimate in column (3) shows that an increase in 1 in the number of fines per 1000 firms in the subregion leads to a reduction of $13 \%$ in value added per employee (which means that the elasticity of productivity with respect to enforcement is approximately 0.1). Our results suggest that, if anything, our estimates in column (1) are likely to be upward biased.

Table 6 gives us indirect evidence that labor flexibility affects firm performance. A simple way to calculate the effect of labor flexibility on firm performance is to divide the coefficient of registration fines from the performance regressions by the analogous coefficient from the informality regressions. Taking the point estimates in column (1) of table 4 and in column (3) of table 6 , the parameters of interest are -4.06 for informal employment and -0.13 for log value added per employee. Therefore, an increase in the proportion of informal employment by 1 percentage point leads to an increase in productivity by $3.2 \%$, and since the average proportion of illegal workers in the sample is $23 \%$ this corresponds to an elasticity of productivity with respect to informal employment of 0.73 . The large magnitude of this elasticity suggests that labor flexibility has very strong effects on firm performance.

Table 7 investigates the effects of changes in enforcement on other measures of firm performance: log sales per employee, log profits per employee, log capital per employee and log total employment. We estimate an equation identical to equation (4.1), with different dependent variables, instrumenting registration fines with total number of train stations in the subregion. ${ }^{19}$ Our point estimates show that weaker enforcement of labor regulation are also associated with higher sales and profits per employee. Furthermore, we find that a weaker enforcement of labor regulation is positively associated with total employment in the firm. When faced with the possibility of hiring informal workers firms decide to increase

performance are still positively correlated would lead to a positive bias (IV estimates in columns (3)-(5) would be lower bound estimates).

${ }^{19}$ The regional controls include: total number of plants in the subregion, total current population in the subregion, $\log$ current GDP per capita in the subregion, log past total population in the subregion, $\log$ past GDP per capita in the subregion, share of females in the subregion and in the city, homicide rate in the subregion and log average city area in the subregion and total labor fines in the subregion. Firm characteristics include age of the firm, the share public ownership and industry dummies. Although not reported, the least squares estimates yield similar results (available on request). 
the size of their labor force, taking advantage of the lower labor costs. An increase in 1 in the number of fines per 1000 firms in the subregion leads to a reduction of $19 \%$ in the total size of the firm. We do not find strong evidence that stricter enforcement of the law reduces firm's investment.

\section{Conclusion}

This paper has two main themes. First, we study the incentives firms face to employ informal workers. In particular, we study the role of enforcement of labor regulation (in the form of labor fines) on the behavior of firms. Second, we analyze how enforcement of formal employment affects firm performance. Stricter enforcement reduces the access of firms to unregulated labor and can damage their productivity by increasing labor costs. Using a combination of firm level data on illegal employment and firm performance, and administrative data on enforcement of regulation, we show that law enforcement reduces informal employment by firms. Furthermore, it also reduces the firm's productivity and profitability. We argue that this is due to the firm's limited access to flexible labor. We also find that increased enforcement of labor regulation reduces the firm's use of labor.

In summary, our paper shows that enforcement of labor regulation in the form of fines can be effectively used as a tool for fighting informality. However, our paper also shows that informal employment is an important source of unregulated labor for Brazilian firms, allowing them to operate more efficiently, and increasing the average firm size. Both of these conclusions have important implications for the design of labor regulation and of its enforcement.

\section{Appendix - Data}

The data used in the paper comes from a variety of sources and covers thirteen Brazilian states: Sao Paulo, Rio de Janeiro, Minas Gerais, Santa Catarina, Rio Grande do Sul, Parana, Goias, Mato Grosso, Ceara, Paraiba, Maranhao, Bahia and Amazonas. ${ }^{20}$

The firm level data used is the Brazilian investment climate survey collected by the World

\footnotetext{
${ }^{20}$ Brazil is divided into 5 regions (North, Northeast, Center-West, Southeast and South) and 27 states.
} 
Bank in 2003. ${ }^{21}$ The criteria used for the sample selection was the representativeness of the population in the specified industrial and regional categories, and diversity in the firm size. To account for these considerations a random sample was stratified using employment has weights. The sample frame covered all the registered firms in the following industrial sectors: food, textile, garments, chemicals, machinery, electronic equipment, auto components and wood products. The selected industries together account for more than $75 \%$ of the manufacturing value added and employment in 2002. The first part of the survey, collects information on different topics: general information about the firm and its manager, business environment and business relations, services and government regulations, labor and human resources, production capacity, planning and innovations, supplier and client relations, infrastructure and services inspections, finance. The second part of the survey collects balance sheet information for the 2000-2002 period.

In the collection of this dataset the World Bank worked with a private survey firm. Given the detail and the sensitive nature of some of the questions the survey was designed to be answered by the firm's manager. The typical observation is based on a three-hour interview which often implied two visits to the firm to accommodate the manager's time schedule. This resulted in a sample of 1,641 firms with information on several characteristics of the firm, such as total employment, sales, value added, labor costs, capital stock, share of high educated workers, share of workers with training, age of the firm and share of foreign and public ownership. These firms are located across 306 cities and 77 subdelegacias in Brazil.

The construction of the main variables in the paper for 2002 was as follows: Employment is the total number of workers in the firm in 2002, Sales per employee is the total sales divided by total number of employees, Value added per employee is the firm's value added divided by the total number of employees, Capital per employee is total value of machinery and equipment at the end of 2002, excluding depreciation, divided by total number of employees, Share of high educated workers is the share of workers with at least the secondary education, Share of females is the share of females in total workforce, Share public (foreign) ownership

\footnotetext{
${ }^{21}$ Previous similar data projects within the World Bank include the Regional Program on Enterprise Development, that has been collecting firm-level data in Sub-Saharan Africa countries for a decade, and the World Business Environment Survey.
} 
is the share of the firm's capital owned by public (foreign) owners, Tax evasion is the share of the firm's total sales not reported for tax purposes, Bribes is the contract's share that is expected in bribes to obtain the contract when doing business with the government.

Data on the enforcement of labor regulation in 2002 comes from the Brazilian Ministry of Labor. It is the Ministry's responsibility to enforce all the laws and regulations, including international conventions, related with labor and employment relations and contracts. The inspectors verify the enforcement of labor related laws and regulations. In particular, they try to avoid labor informality verifying that workers are formally registered with the labor authorities, i.e., that they have a work permit (or carteira de trabalho). The Ministry of Labor is a decentralized structure with a regional branch in each state (delegacia regional do trabalho). Within each branch, there are several administrative units, or subdelegacias. The concept of subdelegacia is administrative and does not correspond to any geographical unit. In particular, a subdelegacia includes more than one city (or municipio). In each subdelegacia there are several regional offices, of which one is the headquarters. The regional offices are not decision units like the subdelegacias. They are designed for increasing the access of the public to the Ministry of Labor.

The inspector responsible for each subdelegacia, or the subdelegado, reports to the inspector responsible for the regional branch, the delegado. The labor inspectors are affiliated only with one subdelegacia. In general, each inspector works only for one subdelegacia and reports to the subdelegado. The inspectors visit the plants with the objective of evaluating the compliance with several dimensions of the labor laws and regulations.

We have administrative data collected by the Ministry of Labor in 2002 at the city level for fines related with different labor violations: informal worker fines, are fines related with the firm not registering the worker for a work permit, work load fines are fines related with the firm not complying with the official work load, wage fines are fines related with the firm not paying the minimum established by the law, hours of work fines are fines related with the firm not complying with the number of hours of work and the mandatory pauses, FGTS fines are fines related with the firm not making the mandatory discounts to the FGTS, transport subsidy fines are fines related with firm not paying the mandatory transport subsidy, and 
other fines are fines related with other mandatory obligations of the firm to their workers. We construct the total labor fines, as the sum of all these different fines. We also have information on the number of regional offices in each subregion, number of inspected firms and the number of fines issued in each city.

Finally, we also use information from two Brazilian statistical and research institutes (IPEA and IBGE). Data for population in 2000 and 1996 and for the total number of plants in 2002 is collected by the National Statistics Institute (IBGE) at the city level. City level data for GDP (2000 and 1996), share of females (2000), geographical area (2000), index in transportation costs to the nearest capital city (1995), number of train stations in the city (1995) and homicide rate per 100 thousand inhabitants (2002) is collected by the Instituto de Pesquisa Economica Aplicada (IPEA). We construct GDP per capita in the subregion dividing GDP by the total population in 2000 in the subdelegacia and past GDP per capita in the subregion dividing GDP by the total population in 1996.

All the enforcement measures and the control variables described above are available at the city level. To obtain the corresponding variables at the subregion level, we aggregate the variables from city to the subregion level using information provided by the Ministry of Labor on all the cities that belong to each subdelegacia. 


\section{References}

[1] Bar-Ilan, Avner and Bruce Sacerdote, "Response to Fines and Probabilities in a Natural Experiment", Journal of Law and Economics, XLVII (2004).

[2] Barros, Ricardo Paes and C. Corseuil, "The impact of regulations on Brazilian Labor Market Performance". InterAmerican Development Bank Research Paper No. 427, 2001.

[3] Becker, Gary, "Crime and Punishment: An Economic Approach", Journal of Political Economy, LXXVI (1962), 169-217.

[4] Besley, Timothy and Robin Burgess, "Can Labor Regulation Hinder Economic Performance? Evidence from India", Quarterly Journal of Economics, CXIX (2004), 91-134.

[5] Blanchard, Olivier and Justin Wolfers, "The role of shocks and institutions in the rise of european unemployment: aggregate Evidence", Economic Journal, CX(2000), 1-33.

[6] Blau, F. and L. Kahn, "International Differences in Male Wage Inequality: Institutions versus Market Forces", Journal of Political Economy, CIV(1996), 791-837.

[7] Boeri, Tito and Juan Jimeno, "The Effects of Employment Protection: Learning from Variable Enforcement", European Economic Review, XLIX (2005), 2057-2077.

[8] Botero, Juan, Simeon Djankov, Rafael La Porta, Florencio Lopez-de-Silanes, and Andrei Shleifer, "The Regulation of Labor", Quarterly Journal of Economics, CXIX(2004), $1339-1382$.

[9] Gruber, Jonathan, "The Incidence of Payroll Taxation: Evidence from Chile", Journal of Labor Economics, XV(1997), 72-101.

[10] De Soto, Hernando, The Other Path: The Invisible Revolution in the Third World, (New York: Harpercollins, 1989).

[11] Freeman, Richard, "Labor Market Institutions and Economic Performance", Economic Policy, VI (1988), 64-80.

[12] Heckman, James and Carmen Pages, Law and Employment: Lessons from Latin American and the Caribbean (Chicago: The University of Chicago Press for the NBER, 2003).

[13] Holmes, Thomas, "The Effect of State Policies on the Location of Manufacturing: Evidence from State Borders", Journal of Political Economy, CVI (1998), 667-705.

[14] Johnson, Simon, Daniel Kaufmann and Pablo Zoido-Lobaton, "Regulatory discretion and the unofficial economy", American Economic Review, LXXXVIII (1998), 387-392.

[15] Kugler, Adriana and Kugler, Maurice, "The Labor Market Effects of Payroll Taxes in a middle Income country: Evidence from Colombia". CEPR Discussion Paper No. 4046, 2003.

[16] Lazear, Edward, "Job Security Provisions and Employment" Quarterly Journal of Economics, CV(1990), 699-726. 
[17] Levitt, Steve, "Using Electoral Cicles in Police Hiring to Estimate the Effect of Police on Crime", American Economic Review, LXXXVII (1997), 270-290.

[18] Levitt, Steven, "Juvenile Crime and Punishment", Journal of Political Economy, CVI(1998), 1156-1185.

[19] Levitt, Steven, "Understanding Why Crime Fell in the 1990s: Four Factors that Explain the Decline and Six that Do Not", Journal of Economic Perspectives, XVIII(2004), 163190.

[20] Loayza, Norman, "The Economics of the Informal Sector: A Simple Model and Some Empirical Evidence from Latin America", Carnegie-Rochester Conference Series on Public Policy, XLV(1996), 129-62.

[21] Loayza, Norman, Ana Oviedo and Luis Serven, "The Impact of Regulation on Growth and Informality: Cross Country Evidence", World Bank Policy Working Paper No 3623, 2005.

[22] Maloney, William, "Informality Revisited", World Development, XXXII(2004), 1159-78.

[23] Nickell, Stephen, "Unemployment and Labor Market Rigidities: Europe versus North America", Journal of Economic Prespectives, XI(1997), 55-74.

[24] Nickell, Stephen and Richard Layard, "Labor Market Institutions and Economic Performance", in O. Ashenfelter and D. Card, eds., Handbook of Labor Economics (Amsterdam: North Holland, 2000).

[25] Oi, Walter, "Labor as a Quasi-fixed Factor", Journal of Political Economy, LXX(1962), 538-555.

[26] Polinsky, Mitchell and Shavell, Steven "The Economic Theory of Public Enforcement of Law", Journal of Economic Literature, XXXVIII(2000), 45-76.

[27] Scarpetta, Stefano and T. Tressel, "Boosting productivity via innovation and adoption of new technologies: any role for labor market institutions?" World Bank Discussion Paper, 2004.

[28] Schneider, Friedrich and Dominik H. Enste, "Shadow Economies: Size, Causes, and Consequences", Journal of Economic Literature, XXXVIII(2000), 77-114.

[29] Svensson, Jakob, "Who must pay bribes and how much? Evidence from a cross section of firms", Quarterly Journal of Economics, CXVIII(2003), 207-230. 
Table 1: Differences between firms with and without informal labor

\begin{tabular}{|c|c|c|}
\hline & $\begin{array}{l}\text { Without Regional } \\
\text { and Sector Controls }\end{array}$ & $\begin{array}{c}\text { With Regional and } \\
\text { Sector Controls }\end{array}$ \\
\hline & $(1)$ & $(2)$ \\
\hline \multirow[t]{2}{*}{ Log employment } & -0.77 & -0.67 \\
\hline & {$[0.066]^{* * *}$} & {$[0.060]^{* * *}$} \\
\hline \multirow[t]{2}{*}{ Log sales per employee } & -0.82 & -0.48 \\
\hline & {$[0.102]^{* * *}$} & {$[0.062]^{* * *}$} \\
\hline \multirow[t]{2}{*}{ Log value added per employee } & -0.76 & -0.46 \\
\hline & {$[0.103]^{* * *}$} & {$[0.069]^{* * *}$} \\
\hline \multirow[t]{2}{*}{ Log capital per employee } & -0.78 & -0.427 \\
\hline & {$[0.138]^{* * *}$} & {$[0.098] * * *$} \\
\hline \multirow[t]{2}{*}{ Share of high educated workers } & -0.06 & -0.031 \\
\hline & {$[0.016]^{* * *}$} & {$[0.015]^{* *}$} \\
\hline \multirow[t]{2}{*}{ Share of females in workforce } & 0.08 & -0.008 \\
\hline & {$[0.018]^{* * *}$} & {$[0.010]$} \\
\hline \multirow[t]{2}{*}{ Age of the firm } & -6.73 & -4.96 \\
\hline & {$[1.113]^{* * *}$} & {$[0.911]^{* * *}$} \\
\hline \multirow[t]{2}{*}{ Share public ownership in the firm } & -0.004 & -0.003 \\
\hline & {$[0.002]^{*}$} & {$[0.002]$} \\
\hline \multirow[t]{2}{*}{ Share foreign ownership in the firm } & -0.066 & -0.044 \\
\hline & {$[0.017]^{* * *}$} & {$[0.011]^{* * *}$} \\
\hline \multirow[t]{2}{*}{ Food Products } & -0.05 & - \\
\hline & {$[0.018] * * *$} & \\
\hline \multirow[t]{2}{*}{ Textile Products } & -0.04 & - \\
\hline & {$[0.016]^{* *}$} & \\
\hline \multirow[t]{2}{*}{ Clothing } & 0.16 & - \\
\hline & {$[0.022]^{* * *}$} & \\
\hline \multirow[t]{2}{*}{ Shoes and Leather Products } & 0.04 & - \\
\hline & {$[0.019]^{* *}$} & \\
\hline \multirow[t]{2}{*}{ Chemicals } & -0.06 & - \\
\hline & {$[0.022]^{* * *}$} & \\
\hline \multirow[t]{2}{*}{ Machinary } & -0.05 & - \\
\hline & {$[0.020]^{* *}$} & \\
\hline \multirow[t]{2}{*}{ Electronical Equipment } & -0.03 & - \\
\hline & {$[0.013]^{* *}$} & \\
\hline \multirow[t]{2}{*}{ Auto Components } & -0.04 & - \\
\hline & {$[0.019]^{* *}$} & \\
\hline \multirow[t]{2}{*}{ Wood Products } & 0.08 & - \\
\hline & {$[0.023] * * *$} & \\
\hline \multirow[t]{2}{*}{ Tax evasion in the firm } & 0.17 & 0.14 \\
\hline & {$[0.014] * * *$} & {$[0.014]^{* * *}$} \\
\hline \multirow[t]{2}{*}{ Bribes for government contracts in the firm } & 0.05 & 0.04 \\
\hline & {$[0.009]^{* * *}$} & {$[0.009]^{* * *}$} \\
\hline
\end{tabular}

Source: Investment Climate Survey Brazil (2002)

The numbers reported in column (1) are the coefficients of a least square regression of each variable on a dummy variable that assumes the value one if the firm reports a positive share of informal workers. Column (2) adds industry dummies and subregional variables (log total number of plants in the subregion, log of population in the subregion in 2000 and the log of GDP per capita in 2000). Standard errors are clustered at the subregional level. * significant at 10\%; ** significant at $5 \%$;** significant at $1 \%$. See data appendix for the sources and definition of the variables. 
Table 2:

Determinants of Enforcement in Brazil

\begin{tabular}{|c|c|c|c|c|}
\hline Dependent Variable: & $\begin{array}{l}\text { Registration } \\
\text { Fines per } \\
1000 \text { firms } \\
\text { subregion }\end{array}$ & $\begin{array}{l}\text { Registration } \\
\text { Fines per } \\
1000 \text { firms } \\
\text { subregion }\end{array}$ & $\begin{array}{l}\text { Registration } \\
\text { Fines per } \\
1000 \text { firms } \\
\text { subregion }\end{array}$ & $\begin{array}{c}\text { Registration } \\
\text { Fines per } \\
1000 \text { firms } \\
\text { subregion }\end{array}$ \\
\hline \multirow[t]{2}{*}{ Method: } & OLS & OLS & OLS & OLS \\
\hline & $(1)$ & $(2)$ & (3) & $(4)$ \\
\hline Log total number of plants in the subregion & $\begin{array}{c}-0.491 \\
{[0.117]^{* * *}}\end{array}$ & $\begin{array}{c}-0.489 \\
{[0.111] * * *}\end{array}$ & $\begin{array}{l}-0.021 \\
{[0.111]}\end{array}$ & $\begin{array}{l}-0.049 \\
{[0.103]}\end{array}$ \\
\hline Log GDP per capita in the subregion & $\begin{array}{c}-0.445 \\
{[0.396]}\end{array}$ & $\begin{array}{c}-0.744 \\
{[0.385]^{*}}\end{array}$ & $\begin{array}{l}-0.219 \\
{[0.304]}\end{array}$ & $\begin{array}{c}-0.496 \\
{[0.290]^{*}}\end{array}$ \\
\hline Log total population in the subregion & $\begin{array}{l}-0.438 \\
{[1.953]}\end{array}$ & $\begin{array}{c}1.524 \\
{[1.932]}\end{array}$ & $\begin{array}{l}-1.014 \\
{[1.490]}\end{array}$ & $\begin{array}{c}0.634 \\
{[1.448]}\end{array}$ \\
\hline Log past GDP per capita in the subregion & $\begin{array}{c}0.761 \\
{[0.358]^{* *}}\end{array}$ & $\begin{array}{c}0.82 \\
{[0.338]^{* *}}\end{array}$ & $\begin{array}{c}0.123 \\
{[0.287]}\end{array}$ & $\begin{array}{c}0.211 \\
{[0.266]}\end{array}$ \\
\hline Log past total population in the subregion & $\begin{array}{c}0.881 \\
{[1.985]}\end{array}$ & $\begin{array}{l}-1.391 \\
{[1.992]}\end{array}$ & $\begin{array}{c}1.055 \\
{[1.512]}\end{array}$ & $\begin{array}{c}-0.844 \\
{[1.489]}\end{array}$ \\
\hline Share of Females in the subregion & $\begin{array}{c}-7.356 \\
{[3.656]^{* *}}\end{array}$ & $\begin{array}{l}-3.708 \\
{[3.614]}\end{array}$ & $\begin{array}{l}-2.547 \\
{[2.867]}\end{array}$ & $\begin{array}{c}0.161 \\
{[2.750]}\end{array}$ \\
\hline Homicide rate in the subregion & $\begin{array}{c}-0.006 \\
{[0.006]}\end{array}$ & $\begin{array}{c}-0.003 \\
{[0.005]}\end{array}$ & $\begin{array}{c}-0.008 \\
{[0.004]^{*}}\end{array}$ & $\begin{array}{l}-0.006 \\
{[0.004]}\end{array}$ \\
\hline Log average city area in the subregion & $\begin{array}{c}-0.161 \\
{[0.096]^{*}}\end{array}$ & $\begin{array}{c}-0.209 \\
{[0.116]^{*}}\end{array}$ & $\begin{array}{l}-0.066 \\
{[0.074]}\end{array}$ & $\begin{array}{c}-0.046 \\
{[0.089]}\end{array}$ \\
\hline Number of train stations in the subregion & - & $\begin{array}{c}0.024 \\
{[0.007]^{* * *}}\end{array}$ & - & $\begin{array}{c}0.02 \\
{[0.006]^{* * *}}\end{array}$ \\
\hline Total labor fines per 1000 firms in the subregion & - & - & $\begin{array}{c}0.128 \\
{[0.018]^{* * *}}\end{array}$ & $\begin{array}{c}0.133 \\
{[0.384]}\end{array}$ \\
\hline $\begin{array}{l}\text { Observations } \\
\text { R squared }\end{array}$ & $\begin{array}{c}77 \\
0.31\end{array}$ & $\begin{array}{c}77 \\
0.40\end{array}$ & $\begin{array}{c}77 \\
0.60\end{array}$ & $\begin{array}{c}77 \\
0.67\end{array}$ \\
\hline
\end{tabular}

The table reports the least squares escing of a regression of registaion fines per 1000 fims in the subregion on different explariory variables at

the subregional level. Standard errors in brackets, * significant at 10\%; ** significant at $5 \%$; *** significant at $1 \%$. The regressions includes one observation per subregion in our sample. Number of train stations is the total number of train stations in the subregion, Average city area is the average area of the city in the subregion and Homicide rate is the average number of homicides per 100 thousand inhabitants in the subregion. We construct log per capita GDP and log total population using data for 2000, log past per capita GDP and log past total population using data for 1996 and log total number of plants using data for 2002. See data appendix for the sources and definition of the variables. 
Table 3

Enforcement and Informality in Brazil

Dependent Variable:

Share of informal Share of informal Share of informal

Workers Workers Workers

Method:

OLS

OLS

OLS

Registration fines per 1000 firms in the subregion

(1)

(2)

(3)

$-2.14$

$-2.56$

$-2.19$

Age of the firm

$[0.58]^{* * *}$

$[0.83]^{* * *}$

$[0.81]^{* * *}$

$-$

$-0.14$

$-0.14$

Share females in the city

$-$

$[0.04] * * *$

$[0.04]^{* * *}$

Share public ownership of the firm

54.41

68.62

$[30.17]^{*}$

$[30.55]^{* *}$

$-20.42$

$-18.52$

Homicide rate per 100000 inhabitants in the subregion

$[8.79]^{* *}$

$[8.84]^{* *}$

$-$

-

0.12

$[0.06]^{* *}$

Regional Controls Included?

$\mathrm{N}$

No

Yes

Yes

Industry Dummies Included?

No

Yes

Yes

Observations

1,473

1,473

1,473

R squared

0.01

0.08

0.08

The table reports the least squares estimates of equation (4.1). Standard errors in brackets and clustered at the subregion level. * significant at $10 \%$; ** significant at 5\%; *** significant at $1 \%$. Regional controls includes log total number of plants in the subregion, log total population in the subregion, $\log$ GDP per capita in the subregion, log past total population in the subregion, log past GDP per capita in the subregion, share of females in the subregion, and $\log$ average city area in the subregion. See data appendix for the sources and definition of the variables. 
Table 4:

Enforcement and Informality: 2SLS Estimates

\begin{tabular}{|c|c|c|c|c|c|}
\hline Dependent Variable: & $\begin{array}{l}\text { Share of } \\
\text { informal } \\
\text { Workers }\end{array}$ & $\begin{array}{l}\text { Share of } \\
\text { informal } \\
\text { Workers }\end{array}$ & $\begin{array}{l}\text { Share of } \\
\text { informal } \\
\text { Workers }\end{array}$ & $\begin{array}{l}\text { Share of } \\
\text { informal } \\
\text { Workers }\end{array}$ & $\begin{array}{l}\text { Share of } \\
\text { informal } \\
\text { Workers }\end{array}$ \\
\hline \multirow[t]{2}{*}{ Method: } & 2SLS & 2SLS & 2SLS & 2SLS & 2SLS \\
\hline & (1) & (2) & (3) & (4) & (5) \\
\hline Registration fines per 1000 firms in the subregion & $\begin{array}{c}-4.06 \\
{[2.02]^{* *}}\end{array}$ & $\begin{array}{c}-4.12 \\
{[1.76]^{* *}}\end{array}$ & $\begin{array}{c}-4.67 \\
{[2.29]^{* *}}\end{array}$ & $\begin{array}{c}-4.43 \\
{[1.94]^{* *}}\end{array}$ & $\begin{array}{c}-3.27 \\
{[1.75]^{*}}\end{array}$ \\
\hline Transportation Costs & - & $\begin{array}{l}-0.69 \\
{[5.61]}\end{array}$ & $\begin{array}{c}-2.86 \\
{[4.83]}\end{array}$ & $\begin{array}{c}0.05 \\
{[4.85]}\end{array}$ & $\begin{array}{c}-2.67 \\
{[5.40]}\end{array}$ \\
\hline Total labor fines per 1000 firms in the subregion & - & - & $\begin{array}{c}0.46 \\
{[0.44]}\end{array}$ & - & - \\
\hline Tax evasion in the firm & - & - & - & $\begin{array}{c}28.53 \\
{[3.17]^{* * * *}}\end{array}$ & - \\
\hline Bribes to government oficials in the firm & - & - & - & - & $\begin{array}{c}6.69 \\
{[2.09]^{* * *}}\end{array}$ \\
\hline Regional controls included? & Yes & Yes & Yes & Yes & Yes \\
\hline Firm controls included? & Yes & Yes & Yes & Yes & Yes \\
\hline Instrument & $\begin{array}{l}\text { Number of train } \\
\text { stations }\end{array}$ & $\begin{array}{c}\text { Number of train } \\
\text { stations }\end{array}$ & $\begin{array}{c}\text { Number of train } \\
\text { stations }\end{array}$ & $\begin{array}{c}\text { Number of train } \\
\text { stations }\end{array}$ & $\begin{array}{c}\text { Number of train } \\
\text { stations }\end{array}$ \\
\hline$F$-test instruments & 5.61 & 7.16 & 7.06 & 7.49 & 8.63 \\
\hline$p$ value & 0.02 & 0.01 & 0.01 & 0.01 & 0.004 \\
\hline Observations & 1,473 & 1,473 & 1,473 & 1,398 & 985 \\
\hline $\mathrm{R}$ squared & 0.077 & 0.077 & 0.078 & 0.100 & 0.140 \\
\hline
\end{tabular}


Table 5:

Enforcement and Tax Evasion in Brazil

\begin{tabular}{lcc}
\hline \hline Dependent Variable: & $\begin{array}{c}\text { Share Sales } \\
\text { Unreported Tax } \\
\text { Authority }\end{array}$ & $\begin{array}{c}\text { Share Sales } \\
\text { Unreported Tax } \\
\text { Authority }\end{array}$ \\
Method: & OLS & 2SLS \\
\hline & $(1)$ & $(2)$ \\
\hline Registration fines per 1000 firms in the subregion & 0.002 & -0.010 \\
& {$[0.006]$} & {$[0.015]$} \\
Regional controls included? & Yes & Yes \\
Firm characteristics included? & Yes & Yes \\
Instrument & - & Number of train \\
& & stations \\
Observations & 1,511 & 1,511 \\
R squared & 0.10 & 0.10 \\
\hline \hline
\end{tabular}

The table reports the estimates of equation (4.1) in the text when the dependent variable is the share of sales unreported for tax purposes. Standard errors in brackets and clustered at the subregion level. * significant at 10\%; ** significant at 5\%; *** significant at $1 \%$. Column reports the least square estimate and columns (2) and (3) report instrumental variables estimates. Regional controls include: log total number of plants in the subregion, log total population in the subregion, log GDP per capita in the subregion, log past total population in the subregion, log past GDP per capita in the subregion, share of females in the subregion and in the city, homicide rate in the subregion and log average city area in the subregion. Firm characteristics include age of the firm, the share public ownership and industry dummies. See data appendix for the sources and definition of the variables. 
Table 6:

Enforcement and Labor Productivity in Brazil

$\begin{array}{ll}\text { Dependent Variable: } & \text { Value Added Value Added Value Added Value Added Value Added } \\ \text { per Employee per Employee per Employee per Employee per Employee }\end{array}$

\begin{tabular}{|c|c|c|c|c|c|}
\hline Method: & OLS & OLS & 2SLS & 2SLS & 2SLS \\
\hline & $(1)$ & $(2)$ & $(3)$ & (4) & (5) \\
\hline Registration fines per 1000 firms in the subregion & $\begin{array}{c}-0.10 \\
{[0.039]^{* *}}\end{array}$ & $\begin{array}{c}-0.06 \\
{[0.034]^{*}}\end{array}$ & $\begin{array}{c}-0.13 \\
{[0.060]^{* *}}\end{array}$ & $\begin{array}{c}-0.11 \\
{[0.058]^{*}}\end{array}$ & $\begin{array}{c}-0.14 \\
{[0.069]^{* *}}\end{array}$ \\
\hline Homicide rate per 100000 inhabitants in the subregion & - & $\begin{array}{c}-0.004 \\
{[0.002]^{*}}\end{array}$ & $\begin{array}{c}-0.005 \\
{[0.002]^{* *}}\end{array}$ & $\begin{array}{c}-0.004 \\
{[0.002]^{* *}}\end{array}$ & $\begin{array}{c}-0.004 \\
{[0.002]^{* *}}\end{array}$ \\
\hline Transportation Costs in the subregion & - & - & - & $\begin{array}{c}0.225 \\
{[0.142]}\end{array}$ & $\begin{array}{c}0.168 \\
{[0.156]}\end{array}$ \\
\hline Total labor fines per 1000 firms in the subregion & - & - & - & - & $\begin{array}{c}0.028 \\
{[0.017]^{*}}\end{array}$ \\
\hline Regional Controls Included? & No & Yes & Yes & Yes & Yes \\
\hline Industry Dummies Included? & No & Yes & Yes & Yes & Yes \\
\hline Instrument & - & - & $\begin{array}{l}\text { Number of } \\
\text { train stations }\end{array}$ & $\begin{array}{c}\text { Number of train } \\
\text { stations }\end{array}$ & $\begin{array}{l}\text { Number of train } \\
\text { stations }\end{array}$ \\
\hline Observations & 1,478 & 1,478 & 1,478 & 1,478 & 1,478 \\
\hline R squared & 0.005 & 0.276 & 0.265 & 0.267 & 0.270 \\
\hline
\end{tabular}


Table 7:

Enforcement and Firm Performance in Brazil

\begin{tabular}{lcccc}
\hline \hline Dependent variable: & $\begin{array}{c}\text { Ln Output per } \\
\text { Employee } \\
\text { 2SLS }\end{array}$ & $\begin{array}{c}\text { Ln Profits per } \\
\text { Employee } \\
\text { Method: }\end{array}$ & $\begin{array}{c}\text { Ln Capital per } \\
\text { Employee }\end{array}$ & $\begin{array}{c}\text { Ln Total } \\
\text { Employment }\end{array}$ \\
\hline & $(1)$ & $(2)$ & $(3)$ & 2SLS \\
\hline Registration fines per 1000 firms in the subregion & -0.14 & -0.33 & -0.01 & -0.19 \\
& {$[0.080]^{*}$} & {$[0.120]^{* * *}$} & {$[0.114]$} & {$[0.111]^{*}$} \\
& & & & \\
Industry characteristics included? & Yes & Yes & Yes & Yes \\
Regional controls included? & Yes & Yes & Yes & Yes \\
Observations & & & & \\
R squared & 1,574 & 1,236 & 1,517 & 1,638 \\
\hline \hline
\end{tabular}

The table reports the instrumental variable estimates of equation (4.1) in the text when the dependent variable is log wages per employee, log sales per employee, log profits per employee, log capital per employee, log total employment and technology dummy variable, respectively. Standard errors in brackets and clustered at the subregion level. * significant at $10 \%$; ** significant at $5 \%$. Regional controls include: total number of plants in the subregion, total current population in the subregion, log current GDP per capita in the subregion, log past total population in the subregion, log past GDP per capita in the subregion, share of females in the subregion and in the city, homicide rate in the subregion and $\log$ average city area in the subregion and total labor fines in the subregion. Firm characteristics include age of the firm, the share public ownership and industry dummies. See data appendix for the sources and definition of the variables 
Table A1: Summary Statistics

\begin{tabular}{|c|c|c|c|c|c|}
\hline & Obs & Mean & Std. Dev. & Min & Max \\
\hline Share Informal Workers & 1,476 & 23.7 & 26.60 & 0 & 100 \\
\hline Ln Employment & 1,641 & 4.0 & 1.14 & 1.8 & 8.9 \\
\hline Ln Sales per Employee & 1,577 & 10.7 & 1.26 & 7.1 & 17.5 \\
\hline Ln Value Added per Employee & 1,480 & 8.9 & 1.33 & 4.1 & 16.7 \\
\hline Ln Wage per Employee & 1,558 & 8.7 & 0.94 & 4.0 & 14.7 \\
\hline Ln Capital per Employee & 1,520 & 7.0 & 1.80 & -2.0 & 14.0 \\
\hline Technology & 1,641 & 0.77 & 0.42 & 0 & 1 \\
\hline Share of High Educated Workers & 1,635 & 0.46 & 0.28 & 0 & 1 \\
\hline Share Females & 1,631 & 0.38 & 0.31 & 0 & 1.0 \\
\hline Share of Workers with Training & 1,520 & 0.29 & 0.33 & 0 & 1 \\
\hline Age of the firm & 1,641 & 18.2 & 17.08 & 0 & 122 \\
\hline Share Public Ownership & 1,641 & 0.002 & 0.03 & 0 & 1 \\
\hline Share Foreign Ownership & 1,641 & 0.05 & 0.20 & 0 & 1 \\
\hline Manuf. Food Products & 1,641 & 0.08 & 0.27 & 0 & 1 \\
\hline Manuf. Textile Products & 1,641 & 0.06 & 0.24 & 0 & 1 \\
\hline Manuf. Clothing & 1,641 & 0.27 & 0.44 & 0 & 1 \\
\hline Manuf. Shoes and Leather Products & 1,641 & 0.11 & 0.31 & 0 & 1 \\
\hline Manuf. Chemicals & 1,641 & 0.05 & 0.22 & 0 & 1 \\
\hline Manuf. Machinary & 1,641 & 0.11 & 0.32 & 0 & 1 \\
\hline Manuf. Electronical Equipment & 1,641 & 0.05 & 0.21 & 0 & 1 \\
\hline Manuf. Auto Components & 1,641 & 0.08 & 0.27 & 0 & 1 \\
\hline Manuf. Wood Products & 1,641 & 0.19 & 0.39 & 0 & 1 \\
\hline Log GDP per capita in the subregion / 1000000000 & 1,640 & 1.97 & 0.47 & 0.5 & 3.1 \\
\hline Log Population in the subregion / 1000000000 & 1,640 & 14.27 & 0.79 & 12.4 & 16.2 \\
\hline Log past GDP per capita in the subregion / 1000000000 & 1,640 & 1.89 & 0.51 & 0.1 & 2.7 \\
\hline Log past Population in the subregion / 1000000000 & 1,640 & 14.19 & 0.79 & 12.4 & 16.1 \\
\hline Share of Females in the subregion & 1,640 & 0.38 & 0.04 & 0.3 & 0.4 \\
\hline Train Stations in the subregion & 1,640 & 5.6 & 16 & 0.0 & 63 \\
\hline Registration fines per 1000 firms in the subregion & 1,638 & 0.77 & 0.90 & 0 & 5.85 \\
\hline Work Load Fines per 1000 firms in the subregion & 1,638 & 0.44 & 0.49 & 0 & 2.48 \\
\hline Hours Fines per 1000 firms in the subregion & 1,638 & 0.53 & 0.71 & 0 & 3.80 \\
\hline Wage Fines per 1000 firms in the subregion & 1,638 & 0.70 & 0.74 & 0 & 4.10 \\
\hline FGTS Fines per 1000 firms in the subregion & 1,638 & 1.57 & 1.52 & 0.02 & 11.0 \\
\hline Transport Subsidy Fines per 1000 firms in the subregion & 1,638 & 0.01 & 0.02 & 0 & 0.2 \\
\hline Other Fines per 1000 firms in the subregion & 1,638 & 1.09 & 1.14 & 0.04 & 7.6 \\
\hline Total Labor Fines per 1000 firms in the subregion & 1,638 & 5.12 & 4.53 & 0.17 & 25.9 \\
\hline
\end{tabular}

Source: Investment Climate Survey Brazil (2003), Brazilian Ministry of Labor (2002), IPEA, IBGE. 
Table A2

Enforcement and Informality: Sensitivity to Enforcement of Other Labor Violations

\begin{tabular}{|c|c|c|c|c|c|c|c|}
\hline Dependent Variable: & $\begin{array}{l}\text { Share of } \\
\text { informal } \\
\text { Workers }\end{array}$ & $\begin{array}{l}\text { Share of } \\
\text { informal } \\
\text { Workers }\end{array}$ & $\begin{array}{l}\text { Share of } \\
\text { informal } \\
\text { Workers }\end{array}$ & $\begin{array}{l}\text { Share of } \\
\text { informal } \\
\text { Workers }\end{array}$ & $\begin{array}{l}\text { Share of } \\
\text { informal } \\
\text { Workers }\end{array}$ & $\begin{array}{l}\text { Share of } \\
\text { informal } \\
\text { Workers }\end{array}$ & $\begin{array}{l}\text { Share of } \\
\text { informal } \\
\text { Workers }\end{array}$ \\
\hline \multirow[t]{2}{*}{ Method: } & OLS & OLS & OLS & OLS & OLS & OLS & OLS \\
\hline & $(1)$ & $(2)$ & (3) & (4) & $(5)$ & $(6)$ & (7) \\
\hline Work load fines per 1000 firms in the subregion & $\begin{array}{c}-2.67 \\
{[2.03]}\end{array}$ & - & - & - & - & - & - \\
\hline Wage fines per 1000 firms in the subregion & - & $\begin{array}{l}-1.18 \\
{[1.33]}\end{array}$ & - & - & - & - & - \\
\hline Hours fines per 1000 firms in the subregion & - & - & $\begin{array}{c}-0.86 \\
{[1.22]}\end{array}$ & - & - & - & - \\
\hline FGTS fines per 1000 firms in the subregion & - & - & - & $\begin{array}{l}-0.12 \\
{[0.72]}\end{array}$ & - & - & - \\
\hline Transport subsidy fines per 1000 firms in the subregion & - & - & - & - & $\begin{array}{c}-9.1 \\
{[28.30]}\end{array}$ & - & - \\
\hline Other fines per 1000 firms in the subregion & - & - & - & - & - & $\begin{array}{c}-0.77 \\
{[0.73]}\end{array}$ & - \\
\hline Total labor fines per 1000 firms in the subregion & - & - & - & - & - & - & $\begin{array}{c}-0.28 \\
{[0.22]}\end{array}$ \\
\hline Regional controls included? & Yes & Yes & Yes & Yes & Yes & Yes & Yes \\
\hline Firm controls included? & Yes & Yes & Yes & Yes & Yes & Yes & Yes \\
\hline Observations & 1,473 & 1,473 & 1,473 & 1,473 & 1,473 & 1,473 & 1,473 \\
\hline $\mathrm{R}$ squared & 0.08 & 0.08 & 0.08 & 0.08 & 0.08 & 0.08 & 0.08 \\
\hline
\end{tabular}

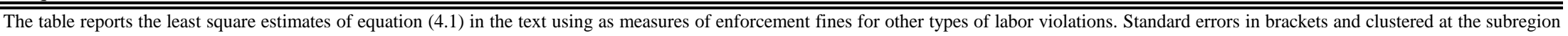

level. * significant at 10\%; ** significant at 5\%; *** significant at 1\%. Regional controls include: log total number of plants in the subregion, log total population in the subregion, log GDP per capita in the subregion, log past total population in the subregion, log past GDP per capita in the subregion, share of females in the subregion and in the city, homicide rate in the subregion and log average city area in the subregion. Firm characteristics include age of the firm, the share public ownership and industry dummies. See data appendix for the sources and definition of the variables. 
Table A3:

Enforcement and Informality:Robustness to Different Selection Criteria

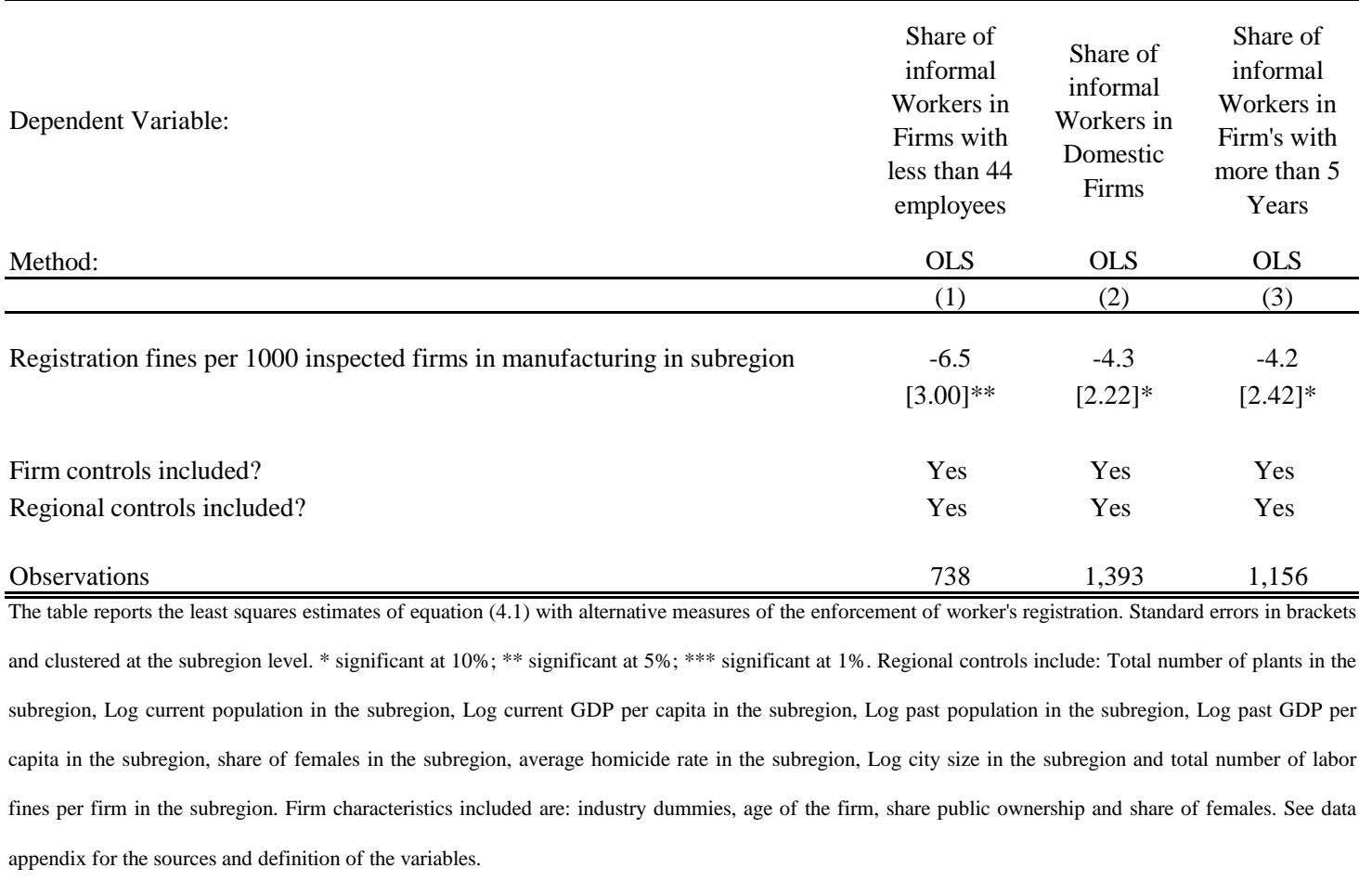

